\title{
HRM, Company Performance and Employee Well-being ${ }^{* *}$
}

This paper is dealing with the relationships between HRM, company performance and employee well-being. The relationship between S/HRM and company performance has received much attention in prior literature, while the employee perspective has been widely neglected in this research tradition. The purpose of this paper is two-fold: first, to identify and evaluate how company performance and employee well-being are related, and, secondly, to evaluate the possibilities of HR policies and practices to impact on company performance and employee well-being. The results indicate that the relationship between company performance and employee well-being is weak and difficult to grasp. And such is the direct link between HRM and employee well-being, which is better explained by typical work-related factors. Instead, HR practices are relatively good predictors of company performance.

Key words: HR Practices, Longitudinal Desing, Competitive Advantage, Organizational Commitment, Organizational Effecteveness, General Satisfaction, Emotional Exhaustion

\footnotetext{
* Sinikka Vanhala, Helsinki School of Economics, PO Box 1210, FIN-00101 Helsinki, Finland, email: sinikka.vanhala@hse.fi.

Kaija Tuomi, Finnish Institute of Occupational Health, Topeliuksenkatu 41 a A, FIN00250 Helsinki, Finland, e-mail: kaija.tuomi@ttl.fi.

** Acknowledgements: The Finnish Work Environment Fund supported this study financially.

Article received: April 27, 2006

Revised version accepted after double blind review: June 2, 2006.
} 


\section{Introduction}

The external environment of companies has encountered a radical change within the past decade. The increased international competition and globalization of businesses have posed new demands for corporate financial result, profitability and shareholder value (Huselid 1995; Becker et al. 2001; Boselie et al. 2005). The restructuring and downsizing of companies and the increasing stringency in the use of labor have in many cases resulted in a positive effect on profitability but a negative one on employees' well-being and workability (Vahtera et al. 1997; McDonough 2000; Dunham 2001). Today, the HR managers and academics have widely internalized the role of HRM in enhancing company performance. Instead, the role of HRM as a guardian of employee well-being is less favorable both among scholars and practitioners. The critical articles on the relationship between HRM and company performance (Guest 2002; Gerhart 2005; Wright/Haggerty 2005) call for building employees into the HRM - performance equation.

The purpose of this paper is two-fold: first, to discuss the role of employee wellbeing in HRM-performance research and to identify and evaluate how company performance and employee well-being are related (or are they?), and, secondly, to evaluate the possibilities of HR policies and practices to impact on company performance and employee well-being. The study applies both company and individual-level data collected in different phases from company management and employees of the same companies in order to construct a logical causal research design, which is less common in prior research (Wright/Haggerty 2005). In addition, several empirical measures of performance and employee well-being are applied in order to triangle the basic concepts of the study.

\section{HRM and company performance}

The impact of HRM or HR practices on company performance has received much attention in prior literature (Huselid 1995; Becker/Gerhart 1996; Guest 1997; Guest et al. 2003; Stravrou/Brewster, 2005). In this tradition human resources are viewed as an integral part of the organizational 'architecture' thus having an impact on organizational effectiveness (Cuthrie et al. 2004). The both concepts, HRM and performance, are problematic to define and measure. There is a vast literature on 'best HR practices', so-called 'High Performance Work Practices' (HPWPs), and 'bundles' of HR practices representing different views of the role of HRM on company performance. Similarly, performance has received much attention representing a multi-level and multidiscipline concept measured at individual, company, and financial level.

Prior research on the link between HR practices and business performance is generally focused on a limited number of generic human resource activities, such as recruitment and selection, training and development, without specifying what constitutes the 'best practice' (Brewster/Larsen 1992; Terpstra/Rozell 1993). More recently, HR bundles and configuration of bundles are applied (MacDuffie 1995; Lähteenmäki et al. 1998; Ichnionovski et al. 1997; Stavrou/Brewster, 2005). However, there seems to be no unanimity of the number or the nature of such practices included in the list (Pfeffer 1994, 1998; Wood 1999; Cho et al. 2005). 
Company performance has been approached, e.g., from economic, psychological or productivity point of view (Guest 1997). There is no one single definition of performance in relation to HRM. It may refer to several things, e.g., improvements in organizational effectiveness without specifying what they might be (Tichy et al. 1982; Devanna et al. 1984), business turnover or other financial measures (ROA and ROE; Delery \& Doty 1996), or a list of short-term and long-term outcomes at the individual and organizational level, e.g., increased commitment and competence, costeffectiveness, and individual well-being and organizational effectiveness (Truss/Gratton 1994; Truss 2001). The 'High Performance Work Practices' (HPWPs) debate has increased the range of performance measures along with the lines of the balanced scorecard (Kaplan/Norton 1992, 1993; Guest 1997; Ulrich 1997). In this tradition, the link is tried to establish between HPWPs and a range of individual and organizational-level outcome variables. Such individual-level outcome variables are, e.g., improved employee abilities, knowledge and skills, increased motivation and commitment. Sustained competitive advantage and productivity are organizational level outcomes, and profits and market value are examples of financial outcomes (Guthrie et al. 2004; Gerhart 2005).

Generally speaking, the positive relationship between HRM or HR practices and organizational performance is widely documented (Huselid 1995; Huselid et al. 1997; Guthrie et al. 2004; Wright et al. 2005). However, the correlations and explained variances remain relatively low, and the criticism is primarily focused on "Missing variables in theories of strategic human resource management: time, cause, and individuals" as Wright and Haggerty (2005) have titled their article. They separate four types of temporal design: 'post-predictive' (HR practices are measured after performance period; predicts past performance), 'retrospective' (respondents were asked to recall HR practices that existed prior to the performance period), 'contemporaneous' (contemporaneous HR practice and performance data), and 'predictive' design.

The causal order is closely related to temporal design. The general assumption seems to be that HR practices are the cause and organizational performance (or other indicator of performance) is the result. However, there are indications of reverse causation, as well (e.g., Vanhala 1991). It means that successful and profitable organizations own slack resources, which they may share with employees in several ways. This all means that a dual causality may exist, or there may exist a one-way relationship to both directions. The third topic in the critical list by Wright and Haggerty (2005) is related to individuals. HR practices are directed to individual employees, and the chain from HR practices to organizational performance goes through employees to operational performance, profitability, and further, to shareholder value. This is called a 'black box' covering the intervening factors between HR practices and company performance. The forth problem in Wright and Haggerty's list is also related to survey design, and it is called the problem of single respondent. The company level HRM survey is typically directed at the HR manager or "the person responsible for HRM" (e.g., Tregaskis et al. 2004). The HR manager may be the best expert in HR strategies and policies. Instead, s/he may be less familiar with the implementation of such strategies and policies and other employee-level issues, as well. (Purcell 1999; Truss 2001; Gerhart 2005; Wright et al. 2005) 


\section{Employee well-being in HRM - company performance equation}

The concept of employee well-being refers to psychological well-being, which consists of several components including affective well-being, job satisfaction, aspiration, anxiety and burnout (Warr 1990, 1994; Ryff/Keyes 1995; Daniels 2000; Holman 2002). Researchers have identified different structures of affective well-being (see, e.g., Daniels 2000), which is why several measures of well-being are applied in this study, as well.

According to prior research, HR practices can have a positive effect on employee well-being. Such HR practices are, for example, training and development, performance appraisal and fair payment system (Spector 1987; Blau 1999; Deery et al. 2002). A study by Browne (2000) focusing on the relationship between HRM practices and organizational effectiveness, employee stress and satisfaction revealed that all measured HRM practices (employee communication, recognition, internal career opportunities and continuous improvement) were positively related to organizational effectiveness and employee satisfaction, and four out of five measures of HR practices were negatively related to stress.

There is a strong relationship between employees' perceived organizational practices related to their own work-organization and employee well-being (Schulz et al. 1995; Kalliath et al. 2000). For example, low levels of personal control are found to be psychologically harmful, while greater levels of control/perceived control over work seem to be associated with higher levels of well-being (Spector 1986; Mullarkey et al. 1997). Instead, there are indications that performance-appraisal and merit-pay systems can contribute to increasing burnout and employee ill-being (Gabris/Ihrke 2001).

There are also HR practices that may have a positive or negative impact on employees depending on the nature of the very practice. For instance, the impact of flexible working hours on well-being is in most cases advantageous - but also disadvantageous depending on, whether employees have control or choice over their work schedules or not (Sparks et al. 2001). According to several studies, the supervisory emotional support serves to buffer or reduce the effects of job stressors (Kirmeyer/Dougherty 1988; Fried/Tiegs 1993), while some studies lack the support for the buffering effect (Kaufmann/Beehr 1986; Burke/Greenglass 1995).

The relationship between company performance and employee well-being is complicated (Harter et al. 2002). Company performance may explain employee wellbeing: successful companies have slack resources and they can afford to invest in employee well-being. Secondly, company financial result may be higher due to laying off people and intensifying work, which may result in ill-being, dissatisfaction and/or burnout of employees. The third alternative for the relationship is that the investments in employee well-being would result in better performance. And forth, employee well-being and company performance are not at all - or only faintly - related to each other. The whole picture is getting more obscure when cross-sectional data with one respondent per company are typically applied. 


\section{Methodology}

\section{Data collection}

Empirical data were gathered from the metal industry and retail trade in Finland. The target groups of the study included the management (company level data; N=91) and employees of these companies (individual level data; $\mathrm{N}=1389$ ). Empirical data were collected by four consecutive surveys. The company level surveys were distributed in 1997 and 1999 and the employee surveys in 1998 and 2000. The target groups consist of those employees who responded in both surveys and their employers, i.e., the same employees in the same companies. In the first phase, 235 companies (1997) and 2599 employees (1998) were involved in the study. In the next phase, part of the companies refused to participate the second survey and some companies were not operating any more (1999) and part of the employees included in the first survey had left the company or did not respond the survey. The final data involve 91 companies and 1389 employees. The follow-up period, from 1997 to 2000, was a period of steady economic growth in Finland.

The research design tries to avoid at least part of the typical problems of prior studies related to "time, causal order and people" (Wright/Haggerty 2005). In this study, HR practices are expected to impact on performance (not vise versa), and employee well-being is at least partly expected to depend on HR practices.

\section{Measures}

The study applies several measures of HR practices (company-level survey, 1997), company performance (company-level survey, 1999) and employee well-being (employee surveys, 1998 and 2000), and also two organizational-level factors: sector (1=retail trade, $2=$ metal industry) and size of the company (10-2100), and workrelated factors, representing employees own views of the situation (employee survey, 1998).

\section{HR practices (company-level survey, 1997)}

The measures of HRM covered the following HR practices: 1) "Formality of HRM", 2) "Recruitment policy", 3) "Employee development", 4) "Motivation and reward", 5) "Employment flexibility", 6) "Team working and participation" and 7) "Communication”. (Pfeffer 1994, 1998; Delery/Doty 1996; Wood 1999; Cho et al. 2005)

1) The formality of HRM was measured by the following indicators: a) "The existence of a written HRM strategy" ( $1=$ Yes, $0=$ No or Don't know), b) "Job descriptions in written" ( $1=$ Yes, $0=$ No or Don't know), c) "A systematic employee absence registration" (1=Yes, $0=$ Partly or Don't know) and d) "A separate industrial health and safety program" ( $1=$ Yes, $0=$ No or Don't know)

2) The indicators of recruitment policy consisted of the following items: a) "Priority of internal recruitment" ranging between 1-3 (low - high), b) "Stringency of recruitment policy" (4 items, ranging from 1-3) ("New employees are recruited as few as possible", "Mainly young employees are recruited", "Only highly skilled employees are recruited" and "State support employees are recruited"). 
3) Employee development was measured by three items: a) "Level of participation in company training" ranging between 1-3 $(1=0-25 \%, 2=26-75 \%$, and $3=$ over $75 \%$ of employees), b) "Investments in training" (1997) ranging between 1-3 (1=less than $1 \%, 2=1-3 \%$, and $3=$ more than $3 \%$ of company turnover) and c) "A manager's evaluation of the employees' opportunities to learn and develop themselves at work" ( 3 =much, 1 =little).

4) Employee motivation and rewarding were measured by two items: a) "Motivating of employees" was measured by a 4-item index: "To which degree do supervisors of this organization:" "support and encourage their subordinates", "discuss problems and other aspects of work", "respect subordinates' work" and "help when needed". A Likert-type 5-point scale ranging from 5 (very much) to 1 (very little) was applied. A 5-point combined scale was formed. The Crohnbach alpha coefficients for the combined scale was: $\alpha=.85$ in 1997. b) "A profit-sharing scheme related to performance pay" ranging from $3=y e s$, for all employees, to $2=y e s$, for part of employees, and $1=$ no.

5) Two kinds of flexibility were measured: a) "Flexible working hours": "working in periods" (1-3), "flexible working hours" (1-3) and "shorter hours" (1-3) and b) Atypical employment relationships were measured by asking the proportions (\%) of employees with "fixed-time" (1-3), "part-time" (1-3) and "temporary contracts" $(1-3)$.

6) Team working and participation

a) The managers were asked to evaluate the proportion of teamwork. A Likert-type scale ranged from 5 (very much) to 1 (very little). The variable was recoded into 3 -point scale ( $3=$ much teamwork, $2=$ moderately, and $1=a$ little teamwork). b) Employee participation was measured by three items: a) "Responsibility delegated to employees and groups of employees", b) "Whether employees are allowed to work independently", and c) Whether work-related targets are set together." A combined variable was formed and classified into three points: 3 (much participation), 2 (moderately), and 1 (a little participation).

7) Communication: The managers evaluated: "The degree of open communication inside and out of the company", "To which degree employees are briefed about the economic performance of the company" and "To which degree work-related problems are openly discussed". A 3-point combined scale was formed.

The company-level means and standard deviations of all the above variables are reported in the next chapter in Table 4

Performance (company-level survey, 1999)

Company performance was measured by gross margin and the manager's evaluation of the economic performance of the company, and by three combined scales comparing performance with other companies in the same field: a) Competitiveness (4 items; "Marketing", "Growth of sales", "Profitability", "Market share”) (Cronbach's $\alpha=.87$ ), b) Customer satisfaction (2 items: "Customer satisfaction", "Quality of products and services") $(\alpha=.86)$ and c) Ability to get employees committed (3 items: "Cooperation between the employer and employees", "Ability to get core employees committed" and "Ability to 
get core employees satisfied" $(\alpha=.78)$. (Dyer/Reeves 1995; Delaney/Huselid 1996; Roos et al. 2004). The reason for using gross margin as a financial measure depends on the fact that the sample covers all sizes of companies (10-2200 employees). Gross margin percent was the only financial figure available also in SMEs.

The means, standard deviations and correlations between performance measures are presented in Table 1. According to table, one company out of four lacks the value of gross margin. In addition, the correlation between gross margin and evaluated economic situation of the company is positive but negative with three other performance measures. The time lag between the financial measure and the evaluated performance measures was one year, which may cause the difference.

Table 1: Means, standard deviations and correlations between performance measures (1999)

\begin{tabular}{l|c|c|c|cccc} 
& range & mean & sd. & 1 PM & 2 MEP & 3 COMP & 4 CUST \\
\hline 1 Profit margin (PM) & $-9,5-$ & 11,43 & 8,79 & & & & \\
2 Mgrs' evaluation of company & 35,8 & & & & & & \\
performance (MEP) & $1-4$ & 3,20 & 0,73 & .16 & & & \\
3 Competitiveness (COMP) & $1-5$ & 3,56 & 0,89 & -.10 & $.39^{* * *}$ & & \\
4 Customer satisfaction (CUST) & $1-5$ & 4,03 & 0,69 & $-.23^{*}$ & $.26^{*}$ & $.40^{* * *}$ & \\
5 Ability to get employees & $1-5$ & 3,73 & 0,76 & -.17 & .11 & $.27^{*}$ & $.36^{* * *}$ \\
committed (COMM) & & & & 70 & 87 & 89 & 89
\end{tabular}

$p<0.05^{*}, p<0.01^{* *}, p<0,001^{* * *}$

Employee well-being (employee surveys, 1998 and 2000)

Employee well-being was measured by three combined scales: 1) A version of GHQ (General Health Questionnaire) (Cooper \& Cartwright, 1994). The items range from 1 (low) to 4 (high) ( $\alpha=.84$ in 1998 and $\alpha=.86$ in 2000). The combined scale of 12 items was recoded into a 5-point scale ranging from 1 to 5. 2) Bradburn's (1969) 5-item scale measures general satisfaction and well-being ranging between 1 and 5 ( $\alpha=.86$ in 1998 and $\alpha=.87$ in 2000). 3) Emotional exhaustion was measured by a modified version of Maslash Burnout Inventory (MBI) (Maslach \& Jackson, 1981). The measure covered 7 items, and the scale applied ranged from 0 (never) to 6 (every day) ( $\alpha=.87$ in 1998 and $\alpha=.89$ in 2000). The scale was recoded into a 5-point scale (1-5).

Table 2: Means, standard deviations and correlations between employee well-being measures

\begin{tabular}{l|c|c|c|ccc}
\hline & range & mean & sd. & $1 \mathrm{GHQ}$ & $2 \mathrm{GS}$ & $3 \mathrm{MBI}$ \\
\hline 1 Psychological well-being (GHQ) & $1-5$ & 3.20 & .90 & & & \\
2 General satisfaction (GS) & $1-5$ & 3.20 & .76 & $.49^{\star \star \star}$ & & \\
3 Emotional exhaustion (MBI) & $1-5$ & 2.03 & 1.03 & $-.61^{* \star *}$ & $-.39^{\star \star *}$ & \\
\hline $\mathrm{N}$ & & & & 1344 & 1333 & 1336
\end{tabular}

$p<0.05^{*}, p<0.01^{* *}$ and $p<0.001^{* * *}$ 
Work-related factors (employee survey, 1998)

The work-related factors represent the employees' own view of the situation in the workplace. The work-related factors measured were: supervisory support (4 items; range $1-5 ; \alpha=.87$ ), conflicts in the workplace (6 items, range $1-5 ; \alpha=.86$ ), job insecurity (5 items; range $0-2 ; \alpha=.65$ ), opportunities for participation (7 items; range 1-5; $\alpha=.85$ ), mental demands at work (3 items; range $1-5 ; \alpha=.71$ ) and physical demands of work (9 items; range 0-2; $\alpha=.86$ ).

\section{Results}

This study takes advantage of several performance indicators and several employee well-being measures in order to better cover the whole area of both concepts and to reveal if some measures would be better than some others in HRM studies.

The relationships between company performance (1999) and employee well-being (in 1998 and 2000) seem to be weak and sporadic. This is the case with the both measures of employee well-being, before the measure of performance and after it. The highest correlations are only .06. An interesting observation is that emotional exhaustion is not related to any company performance measure.

Table 3: Correlations between company level performance measures (1999) and employee well-being indicators (1998 and 2000)

\begin{tabular}{|c|c|c|c|c|c|c|}
\hline & \multicolumn{2}{|c|}{$\begin{array}{l}\text { Psychological } \\
\text { well-being } \\
\text { GHQ }\end{array}$} & \multicolumn{2}{|c|}{$\begin{array}{c}\text { Satisfaction } \\
\text { GS }\end{array}$} & \multicolumn{2}{|c|}{$\begin{array}{c}\text { Emotional } \\
\text { exhaustion } \\
\text { MBI }\end{array}$} \\
\hline & 1998 & 2000 & 1998 & 2000 & 1998 & 2000 \\
\hline Gross margin (GM) & .02 & .04 & .02 & .01 & .02 & -.02 \\
\hline $\begin{array}{l}\text { Mgrs' evaluation of company } \\
\text { performance (MEP) }\end{array}$ & .02 & .05 & $.06^{*}$ & .04 & .03 & .00 \\
\hline Competitiveness (COMP) & .02 & $.06^{*}$ & .02 & $.06^{*}$ & -.01 & .01 \\
\hline $\begin{array}{l}\text { Customer satisfaction } \\
\text { (CUST) }\end{array}$ & -.05 & -.01 & $-.06^{*}$ & .01 & .01 & -.05 \\
\hline $\begin{array}{l}\text { Ability to get employees } \\
\text { committed (COMM) }\end{array}$ & .04 & .03 & .04 & .02 & -.02 & -.01 \\
\hline $\mathrm{N}$ & 1331 & 1320 & 1334 & 1311 & 1241 & 1311 \\
\hline
\end{tabular}

According to correlations, competitiveness seems to have a faint positive correlation with psychological well-being (GHQ) and general satisfaction (GS) in 2000. The size of the organization and the sector were controlled. The size of the organization had no effect on correlations. Instead, the sector was faintly related to general satisfaction and emotional exhaustion. Both satisfaction and emotional exhaustion were a little higher in retail companies than in metal industry.

Human resource practices of this study were measured by 16 variables grouped into seven "bundles". Company performance was measured by five company-level performance indicators. Table 4 summarizes the linear regression models for all five performance indicators. 
Table 4: HRM - performance: Linear regression models for performance indicators, 1999

\begin{tabular}{|c|c|c|c|c|c|c|c|}
\hline HR practices (1997) & $\begin{array}{l}\text { Mean } \\
\mathrm{N}=91\end{array}$ & sd & $\begin{array}{c}\text { Gross } \\
\text { margin }\end{array}$ & $\begin{array}{l}\text { Managers' } \\
\text { evaluation of } \\
\text { econ. } \\
\text { perform }\end{array}$ & $\begin{array}{l}\text { Competi- } \\
\text { tiveness }\end{array}$ & $\begin{array}{l}\text { Customer } \\
\text { satisfact. }\end{array}$ & $\begin{array}{l}\text { Ability to } \\
\text { get } \\
\text { employees } \\
\text { committed }\end{array}$ \\
\hline & & & B & & B & B & \\
\hline \multicolumn{8}{|l|}{ Formality of HRM } \\
\hline Written HR strategy $(0=\mathrm{No}, 1=\mathrm{Yes})$ & 0.33 & .47 & - & - & $.307^{*}$ & & - \\
\hline Written job descriptions (0-1) & 0.66 & .48 & - & - & - & - & - \\
\hline $\begin{array}{l}\text { Systematic absence registration } \\
(0-1)\end{array}$ & 0.56 & .50 & - & $.446^{* * *}$ & - & - & - \\
\hline $\begin{array}{l}\text { Separate health \& safety program } \\
(0-1)\end{array}$ & 0.46 & .50 & - & - & - & - & - \\
\hline \multicolumn{8}{|l|}{ Recruitment policy } \\
\hline Priority of internal recruitment (1-3) & 2.31 & .88 & - & - & - & - & - \\
\hline Stringency of recruitment (1-3) & 2.10 & .70 & - & - & - & - &.- \\
\hline \multicolumn{8}{|l|}{ Employee development } \\
\hline $\begin{array}{l}\text { Level of participation in training } \\
(1-3)\end{array}$ & 2.05 & .91 & - & - & - & - & - \\
\hline Investments in training (1-3) & 1.82 & .74 & $.353^{*}$ & $.308^{*}$ & - & - & - \\
\hline $\begin{array}{l}\text { Opportunities to develop oneself } \\
(1-3)\end{array}$ & 2.41 & .63 & - & - & - & - & - \\
\hline \multicolumn{8}{|l|}{ Motivating \& rewarding } \\
\hline Motivating of employees (1-3) & 2.71 & .54 & - & - & - & - & - \\
\hline Performance-related pay (1-3) & 1.68 & .82 & - & - & - & - & - \\
\hline \multicolumn{8}{|l|}{ Employment flexibility } \\
\hline Flexible working hours $(0-2)$ & 0.99 & .58 & - & - & - & $-.363^{*}$ & - \\
\hline $\begin{array}{l}\text { Atypical employment relations } \\
(0-2)\end{array}$ & 0.92 & .69 & - & - & - & - & - \\
\hline \multicolumn{8}{|l|}{ Teamworking \& participation } \\
\hline Teamworking (1-3) & 2.30 & .77 & - & - & - & - & $.310^{*}$ \\
\hline Participation (1-3) & 2.70 & .51 & - & - & - & - & - \\
\hline \multicolumn{8}{|l|}{ Communication } \\
\hline Communication (1-3) & 2.51 & .67 & - & - & $.314^{*}$ & $.442^{* \star}$ & $.361^{* *}$ \\
\hline $\mathrm{R}^{2}$ & & & .125 & .304 & .264 & .264 & .293 \\
\hline Adjusted $\mathrm{R}^{2}$ & & & .099 & .209 & .231 & .227 & .256 \\
\hline $\mathrm{F}$ & & & $4.841^{*}$ & $9.616^{* * *}$ & $7.908^{* * *}$ & $7.175^{\star \star}$ & $8.071^{\star \star \star}$ \\
\hline
\end{tabular}

The regression analysis revealed that five HR bundles out of seven were related to some performance measure. The explained variance was lowest in gross margin $(13 \%)$ and varied between 26\%-30\% among other performance measures. Investment in training explained gross margin and evaluated economic performance, which got a high beta value in systematic absence registration, too. Communication explained three other performance measures (COMP, CUST, COMM). In addition, "Competitiveness" (COMP) was explained by formality of HRM (Written HR strategy), "Customer satisfaction" (CUST) negatively by flexible working hours, and "Ability to get employees committed" (COMM) by team working. Neither recruitment policy nor motivating and rewarding indicators appeared in regression analysis. 
Table 5 indicates that HR practices have practically no explanatory power in employee well-being issues. The explained variances remained near zero $(2 \%-5 \%)$. Employee development opportunities, communication and company's health and safety program were the main predictors of employee well-being. The highest beta-value was in flexible working hours as a predictor of general satisfaction.

Table 5: HR practices - employee well-being: Linear regression models for employee well-being (1998)

\begin{tabular}{|c|c|c|c|c|c|}
\hline HR practices (1997) & Mean & sd & $\begin{array}{c}\text { Psychological } \\
\text { well-being } \\
\text { B }\end{array}$ & $\begin{array}{c}\text { General } \\
\text { satisfaction } \\
\beta\end{array}$ & $\begin{array}{c}\text { Emotional ex- } \\
\text { haustion } \\
\beta\end{array}$ \\
\hline \multicolumn{6}{|l|}{ Formality of HRM } \\
\hline Written HR strategy ( $0=$ No, $1=Y e s)$ & 0.33 & .47 & - & - & - \\
\hline Written job descriptions (0-1) & 0.66 & .48 & - & - & - \\
\hline Systematic absence registration $(0-1)$ & 0.56 & .50 & - & - & - \\
\hline Separate health \& safety program $(0-1)$ & 0.46 & .50 & $.089^{\star \star}$ & - & $-.141^{* * *}$ \\
\hline \multicolumn{6}{|l|}{ Recruitment policy } \\
\hline Priority of internal recruitment (1-3) & 2.31 & .88 & - & $-.106^{\star \star}$ & - \\
\hline Stringency of recruitment (1-3) & 2.10 & .70 & - & - & - \\
\hline \multicolumn{6}{|l|}{ Employee development } \\
\hline Level of participation in training (1-3) & 2.05 & .91 & - & - & $-.071^{* *}$ \\
\hline Investments in training (1-3) & 1.82 & .74 & - & - & - \\
\hline Opportunities to develop oneself (1-3) & 2.41 & .63 & $-084^{*}$ & $.110^{* *}$ & - \\
\hline \multicolumn{6}{|l|}{ Motivating \& rewarding } \\
\hline Motivating of employees (1-3) & 2.71 & .54 & - & - & - \\
\hline Performance-related pay (1-3) & 1.68 & .82 & - & - & - \\
\hline \multicolumn{6}{|l|}{ Employment flexibility } \\
\hline Flexible working hours $(0-2)$ & 0.99 & .58 & - & $.194^{\star * *}$ & - \\
\hline Atypical employment relations $(0-2)$ & 0.92 & .69 & - & - & - \\
\hline \multicolumn{6}{|l|}{ Teamworking \& participation } \\
\hline Teamworking (1-3) & 2.30 & .77 & - & - & - \\
\hline Participation (1-3) & 2.70 & .51 & - & - & - \\
\hline \multicolumn{6}{|l|}{ Communication } \\
\hline Communication (1-3) & 2.51 & .67 & $.091^{* *}$ & - & $-.120^{\star * *}$ \\
\hline $\mathrm{R}^{2}$ & & & .023 & .053 & .035 \\
\hline Adjusted $\mathrm{R}^{2}$ & & & .019 & .050 & .031 \\
\hline $\mathrm{F}$ & & & $6.449^{\star \star *}$ & $15.471^{* \star *}$ & $9.815^{* \star *}$ \\
\hline
\end{tabular}

The result that there is only a weak direct link from HR practices to employee wellbeing is partly in line with prior results (the existence of the 'black box') partly it needs clarification. The work-place level offers the direct link to employee experiences. That is why the effects of typical work-related factors on employee well-being were analyzed.

The correlation matrix reveals that job insecurity had the lowest correlation with all three well-being indicators. It is logical, because due to sample frame, only those respondents having filled an acceptable questionnaire both in 1998 and 2000 surveys were included in the final sample. The great majority of respondents were thus permanent employees. In regression analyses supervisory support had a statistically signi- 
ficant beta value only in general satisfaction. Conflicts at the workplace, organization of work and opportunities to participate had an impact on all three well-being measures. The total variances explained vary between $17 \%$ and $28 \%$. The results refer to the important role of supervisors and supervisory work in transforming the HR policies and 'official' practices into part of the daily working culture.

Table 6: Means, standard deviations, and correlations between work-related variables and well-being indicators, and regression models for the well-being indicators, 1998

\begin{tabular}{|c|c|c|c|c|c|c|c|c|}
\hline \multicolumn{6}{|c|}{ Correlations } & \multicolumn{3}{|c|}{ Regression models } \\
\hline & Mean & Sd. & $\begin{array}{c}\text { Psycho- } \\
\text { logical } \\
\text { well- } \\
\text { being } \\
r\end{array}$ & $\begin{array}{c}\text { General } \\
\text { satisfaction } \\
r\end{array}$ & $\begin{array}{c}\text { Emotional } \\
\text { exhaustion } \\
r\end{array}$ & $\begin{array}{c}\text { Psycho- } \\
\text { logical } \\
\text { well- } \\
\text { being } \\
\beta\end{array}$ & $\begin{array}{c}\begin{array}{c}\text { General } \\
\text { satisfaction }\end{array} \\
\beta\end{array}$ & $\begin{array}{c}\text { Emotional } \\
\text { exhaustion } \\
\beta\end{array}$ \\
\hline $\begin{array}{l}\text { Supervisory } \\
\text { support (1-5) }\end{array}$ & 2.91 & 0.89 & $.24^{* * *}$ & $.39^{* * *}$ & $-.21^{* \star *}$ & - & $.130^{* * *}$ & - \\
\hline $\begin{array}{l}\text { Conflicts at the } \\
\text { workplace }(6)\end{array}$ & 2.33 & 0.69 & $-.30^{* \star *}$ & $-.28^{* * *}$ & $.36^{* * *}$ & $-.179^{\star \star *}$ & $-.094^{* * *}$ & $.217^{* * *}$ \\
\hline Job insecurity (5) & 0.89 & 0.35 & -.05 & $-.08^{* *}$ & $.09^{* * *}$ & - & $-.055^{*}$ & - \\
\hline Participation (7) & 3.08 & 0.84 & $.26^{* * *}$ & $.37^{* * *}$ & $-.23^{* * *}$ & $.143^{* * *}$ & $.226^{* * *}$ & $-.087^{* * *}$ \\
\hline $\begin{array}{l}\text { Organization of } \\
\text { work (4) }\end{array}$ & 3.29 & 0.68 & $.28^{* \star *}$ & $.42^{\star \star *}$ & $-.28^{\star \star *}$ & $.137^{* \star *}$ & $.233^{\star * *}$ & $-.091^{\star \star *}$ \\
\hline $\begin{array}{l}\text { Mental demands } \\
\text { (3) }\end{array}$ & 3.15 & 0.54 & $-.22^{\star \star \star}$ & $-.07^{* *}$ & $.41^{* \star *}$ & $-.136^{\star * *}$ & - & $.318^{* * *}$ \\
\hline $\begin{array}{l}\text { Physical de- } \\
\text { mands (9) }\end{array}$ & 1.10 & 0.51 & $-.17^{\star \star \star}$ & $-.35^{\star \star *}$ & $.24^{* * *}$ & $-.053^{*}$ & - & $.132^{* * *}-$ \\
\hline \multirow{3}{*}{\multicolumn{6}{|c|}{$\begin{array}{l}\mathrm{R}^{2} \\
\text { Adjusted } \mathrm{R}^{2} \\
\mathrm{~F}\end{array}$}} & .167 & .264 & .284 \\
\hline & & & & & & .164 & .262 & .281 \\
\hline & & & & & & $53.052^{* * *}$ & $94.281^{* * *}$ & $97.206^{\star * \star}$ \\
\hline
\end{tabular}

$\mathrm{p}<0.05^{*}, \mathrm{p}<0.01^{* *}$ and $\mathrm{p}<0.001^{* * *}$

- Beta coefficient not significant

\section{Discussion}

The empirical designs of prior research on HRM and company performance have received strong criticism (Wright et al. 2005; Wright/Haggerty 2005). That is why special attention was paid to research design and measures applied. Cross-sectional survey designs with a single respondent seem to dominate the prior literature. This study took advantage of four survey data collection rounds in the same organizations: two company-level surveys and two employee-level. The design of this study allowed a logical order of measures: HRM/HR practices in 1997, employee well-being in 1998 and 2000 , and company performance in 1999. A weakness of this design is that the final sample may a little biased, because only those companies and employees, who responded in the first surveys and the second ones were accepted. A part of low-performing companies were dropped out of the second company survey, and most temporary workers and those who had left the company between the two employee surveys were left out of the second employee survey. The sample represents thus relatively wellperforming companies and permanent employees. In spite of this bias, the research design allows us to discuss the causal order of events: HR practices seem to impact on 
company performance but not directly on employee well-being. Employee well-being is more strongly effected by work-related and supervisory level issues.

One of the main problems of HRM - company performance studies is the multitude of measures and variables. The list of HR practices applied in prior studies covers almost 30 practices (Wood 1999). Some scholars trust in certain practices, others in "bundles" or configurations of practices (Delery/Doty 1996) or HPWPs (Huselid 1995 Becker \& Gerhart, 1996). Similarly, performance in HRM studies may refer to financial result, productivity, share value, effectiveness, employee behavior (turnover rate, absence rate, commitment, etc.), or customer satisfaction (Guest 1997; Guthrie et al. 2004). In this study, several measures of performance were applied: financial and evaluative measures related to company economic performance, competitiveness, customer satisfaction and ability to get employees committed. The correlation between gross margin and evaluated company economic performance was positive, while that between gross margin and other three performance measures was negative. It means that performance consists of many dimensions, which are not necessarily in line with each other. Ability to get employees committed may be an important target of HRM. However, higher commitment may not result in the bottom line. 'Hard' financial performance measures and 'soft' attitudinal or behavioral performance measures (e.g., satisfaction, commitment) serve different purposes. Especially the role of behavioral performance measures is vague; they are used as a measure of performance, as such, and as a means to (financial) performance.

Employee well-being is also a multi-dimensional concept, whose roots are in psychology and organizational behavior research. Satisfaction, diseases, happiness, worries and burn-out, among others, are included in well-being measures (Maslach/Jackson 1981; Bradburn 1969; Cooper/Cartwright 1994). The results of this study indicate that employee psychological well-being and satisfaction are a little higher and emotional exhaustion lower in companies with health and safety programs, who invest in training and offer developing opportunities to employees and who have created an open communication culture. It means that employee well-being can be increased at least to some degree by HR practices. The observation of low correlations between HRM and employee well-being is logical in this study, because of the hierarchical sampling system, the companies of this study were relatively high performing ones. In addition, it is true that employee well-being is only partly under the control of company HRM. Well-being is primarily an individual-level phenomenon, which is affected by work and non-work issues and individual-level psychological factors. The jump from HRM to employee well-being is too long; it needs a mediating level. Such a mediating level may consist of observations of employees or employees' conceptions of work-related factors. It is more important how employees see or feel than what the facts are. Nothing has changed since the classical Hawthorne studies.

When considering the company performance - employee well-being link from the point of view of HRM, it seems that there is not such a list of HR practices that would simultaneously result in higher performance and higher employee well-being. Instead, further research should be directed both at HRM - performance link and at the link between HRM - employee work and working environment/culture - and 
employee well-being. Efforts to open the 'black box' are needed to better understand the relationships between company-level decisions and employee-level reactions.

\section{References}

Becker, B. / Gerhart, G. (1996): The impact of human resource management on organizational performance: Progress and prospects. In: Academy of Management Journal, 39: 779-801.

Becker, B. / Huselid, M. / Ulrich, D. (2001): The HR scorecard: Linking people, strategy, and performance. Harvard Business School Press.

Blau, G. (1999): Testing the longitudinal impact of work variables and performance appraisal satisfaction on subsequent overall job satisfaction. In: Human Relations, 52 (8): 1099-1113.

Boselie, P. / Dietz, G. / Boon, C. (2005). Commonalities and contradictions in research on human resource management and performance. In: Human Resource Management Journal, 15 (13): 67-94.

Bradburn, N.M. (1969): The structure of psychological well-being. Chicago: Aldine Publishing company.

Brewster, C. / Larsen, H.H. (1992): Human resource management in Europe: evidence from 10 countries. In: International Journal of Human Resource Management 4: 765-783.

Browne, J.H. (2000): Benchmarking HRM practices in healthy work organizations. In: American Business Review, 2000, 2: 54-61.

Burke, R.J. / Greenglass, E.R. (1995): A longitudinal study of psychological burnout of teachers. In: Human Relations, 48: 187-198.

Cho, S. / Woods, R.H. / Jang, S. / Erdem, M. (2005): Measuring the impact of human resource management practices on hospitality firms' performances. Hospitality Management (in press).

Daniels, K. (2000): Measures of five aspects of affective well-being at work. In: Human Relations, 53 (2): 275-294.

Deery, S.J. / Iverson, R.D. / Walsh, J.T. (2002): Work relationships in telephone call centres: understanding emotional exhaustion and employee withdrawal. In: Journal of Management Studies, 39 (4): 471-496.

Delaney, J.T. / Huselid, M.A. (1996): The impact of human resource management practices on perceptions of organizational performance. In: Academy of Management Journal 39 (4): 949-969.

Delery, J.E. / Doty, D.H. (1996): Modes of theorizing in strategic human resource management: tests of universalistic, contingency, and configurational performance predictions. In: Academy of Management Journal, 39 (4): 802-835.

Devanna, M.A. / Fombrun, C. / Tichy, N. / Warren, L. (1984): Strategic planning and human resource management. In: Human Resource Management, 21: 11-17.

Durham, J. (Ed.) (2001): Stress in the workplace. Past, present and future. London: Whurr Publishers.

Dyer, L. / Reeves, T. (1995): Human resource strategies and firm performance: What do we know and where do we need to go? In: International Journal of Human Resource Management, 6 (3): 656-671.

Fried, Y. / Tiegs, R.B. (1993): The main effect model versus buffering model of shop steward social support: A study of rank-and-file auto workers in the U.S.A. In: Journal of Organizational Behavior, 14 (5): 481-493.

Gabris, G.T. / Ihrke, D.M. (2001): Does performance appraisal contribute to heightened levels of employee burnout? The results of one study. In: Public Personnel Management, 30 (2): 157-172.

Gerhart, B. (2005): Human resources and business performance: Findings, unanswered questions, and an alternative approach. In: Management Review ,16 (2): 174-185

Guest, D.E. (1997): Human resource management and performance: a review and research agenda. In: The International Journal of Human Resource Management, 8 (3): 263-276.

Guest, D. (2002): Human resource management, corporate performance and employee wellbeing: Building the worker into HRM. In: The Journal of Industrial Relations 44 (3): 335-358.

Guest, D.E / Michie, J. / Conway, N. / Sheehan, M. (2003): Human resource management and corporate performance in the UK. In: British Journal of Industrial Relations, 41 (2): 291-314.

Guthrie, J.P. / Datta, D.K. / Wright, P.M. (2004): Peeling back the onion. Competitive advantage through people. Test of a causal model. CARHRS, Working Paper 04-09, Cornell University, School of Industrial and Labor Relations. 
Harter, J.K. / Schmidt, F.L. / Hayes, T.L. (2002): Business-unit-level relationship between employee satisfaction, employee engagement, and business outcomes: A meta-analysis. In: Journal of Applied Psychology, 87 (2): 268-279.

Holman, D. (2002): Employee wellbeing in call centres. In: Human Resource Management Journal, 12 (4): 35-50.

Huselid, M.A. (1995): The impact of human resource practices on turnover, productivity and corporate financial performance. In: Academy of Management Journal 38 (3): 635-670.

Huselid, M.A. / Jackson, S.E. / Schuler, R.S. (1997): Technical and strategic human resource management effectiveness as determinants of firm performance. In: Academy of Management Journal, 40 (1): 171-188.

Ichniowski, C. / Shaw, K. / Prennushi, G. (1997): The effects of human resource management practices on productivity: A study of steel finishing lines. In: American Economic Review, 87: 291-312.

Kalliath, T.J. / O'Driscoll, M.P. / Gillespie, D.F. / Bluedorn, A.C. (2000): A test of the Malach burnout inventory in three samples of healthcare professionals. In: Work \& Stress, 14: 35-50.

Kaplan, R.S. / Norton, D.P. (1992): Putting the balanced scorecard to work. In: Harvard Business Review, 70 (5): 134-147.

Kaplan, R.S. / Norton, D.P (1993): The balanced scorecard - measures that drive performance. In: Harvard Business Review, 71 (1): 71-79.

Kaufmann, G.M. / Beehr, T.A. (1986): Interactions between job stressors and social support: Some counterintuitive results. In: Journal of Applied Psychology, 71: 522-526.

Kimeyer, S.L. / Dougherty, T.W. (1988): Work load, tension, and coping: Moderating effect of supervisory support. In: Personnel Psychology, 41: 125-139.

Lähteenmäki S. / Storey J. / Vanhala S. (1998). HRM and company performance: The use of measurement and the influence of economic cycles. In: Human Resource Management Journal, 8 (2): 51-65

MacDuffie, J.P. (1995): Human resource bundles and manufacturing performance: organizational logic and flexible production systems in the world auto industry. In: Industrial and Labor Relations Review, 48 (2): 197-221

Maslach, C. / Jackson, S.E. (1981): The measurement of experienced burnout. In: Journal os Occupational Behaviour, 2: 99-113.

McDonough, P. (2000): Job insecurity and health. In: International Journal of Health Services, 30: 453476.

Mullarkey, S. / Jackson, P.R. / Wall, T.D. / Wilson, J.R. / Grey-Taylor, S.M. (1997): The impact of technology characteristics and job control on worker mental health. In: Journal of Organizational Behavior, 18: 471-489.

Pfeffer, J. (1998): Seven practices of successful organizations. In: California Management Review, 40 (2): 96-124.

Pfeffer, J. (1994): Competitiva advantage through people:Unleashing the power of the work force. Boston: Harvard Business School Press.

Purcell. J. (1999): Best practice and best fit: chimera or cul-de-sac? In: Human Resource Management Journal, 9 (3): 26-41.

Roos, G. / Fernstrom, L. / Pike, S. (2004): Human resource management and business performance measurement. In: Measuring Business Excellence, 8(1): 28-37.

Ryff, C.D / Keyes, C.L.M. (1995): The structure of psychological well-being revised. In: Journal of Personality and Social Psychology, 69: 719-727.

Schulz, R. / Greenley, J.R. / Brown, R. (1995): Organization, management, and client effects on staff burnout. In: Journal of Health and Social Behavior, 36: 333-345.

Sparks, K. / Faragher, B. / Cooper, C. (2001): Well-being and occupational health in the $21^{\text {st }}$ century workplace. In: Journal of Occupational Psychology, 74: 498-509.

Spector, P.E. (1986): Perceived control by employees: A meta-analysis of studies concerning autonomy and participation at work. In: Human Relations, 39: 1005-1016.

Spector, P.E. (1987): Interactive effects of perceived control and job stressors on affective reactions and health outcomes for clerical workers. In: Work and Stress, 1 (2): 155-162. 
Stravrou, E.T. / Brewster, C. (2005): The configurational approach to linking strategic human resource management bundles with business performance: Myth or reality? In: Management Revue, 16 (2): 186-201.

Terpsra, D.E. / Rozell, E.J. (1993): The relationship of staffing practices to organizational level measures of performance. In: Personnel Psychology, 46: 27-48.

Tichy, N.M. / Fombrun, C.J. / Devanna, M.A. (1982): Strategic human resource management. In: Sloan Management Review, 23 (2): 47-61.

Tregaskis, O. / Mahoney, C. / Atterbury, S. (2004): International survey methodology: experiences from the Cranet network. In: C. Brewster / W. Mayrhofer/ M. Morley (Eds.): Human Resource Management in Europe: Evidence of Convergence? Elsevier.

Truss, C. (2001): Complexities and controversies in linking HRM with organizational outcomes. In: Journal of Management Studies, 38 (8): 1121-1149.

Truss, C. / Gratton, L. (1994): Strategic human resource management: a conceptual approach. In: International Human Resource Management, 5 (3): 663-686.

Ulrich, D. (1997): Measuring human resources: an overview of practice and a prescription for results. In: Human Resource Management, 36 (3); 303-320.

Vahtera, J. / Kivimäki, M. / Pentti, J. (1997): Effect of organisational downsizing on health of employees. In: The Lancet, 350: 1124-1128.

Vanhala, S. (1991): Labor flows in the corporate context. A case study of the managerial use of human resources and employee mobility. Acta Academiae Oeconomicae Helsingiensis, Series A.75, Helsinki.

Warr, P. (1990): The measurement of well-being and other aspects of mental health. In: Journal of Occupational Psychology, 63: 193-210.

Wood, S. (1999). Human resource management and performance. In: International Journal of Management Review, 1 (4): 367-413.

Wright, P.M. / Haggerty, J.J. (2005): Missing variables in theories of strategic human resource management: time, cause and individuals. In: Management Review, 16 (2): 164-173.

Wright, P.M. / Gardner, T.M. / Moynihan, L.M. / Allen, M.R. (2005). The relationship between HR practices and firm performance: Examining causal order. In: Personnel Psychology, 58 (2): 409-446. 